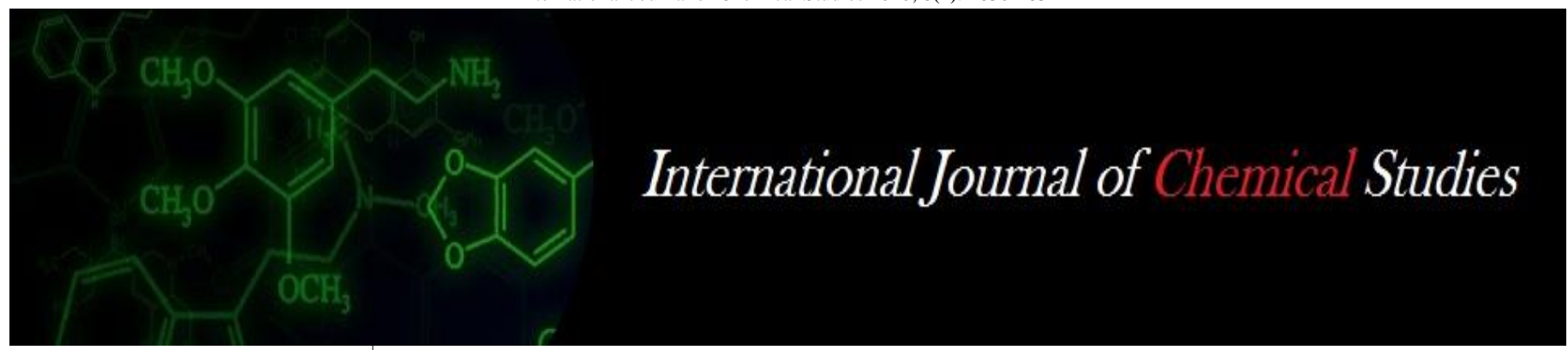

P-ISSN: 2349-8528

E-ISSN: 2321-4902

www.chemijournal.com

IJCS 2020; 8(1): 2830-2834

(C) 2020 IJCS

Received: 10-11-2019

Accepted: 12-12-2019

\section{Rahul Sur}

Department of Post Harvest

Technology, Faculty of

Horticulture, Bidhan Chandra

Krishi Viswavidyalaya,

Mohanpur, Nadia, West Bengal,

India

\section{Achintya Mahato}

Department of Post Harvest

Technology, Faculty of

Horticulture, Bidhan Chandra

Krishi Viswavidyalaya,

Mohanpur, Nadia, West Bengal,

India

\section{Arghya Mani}

Department of Post Harvest

Technology, Faculty of

Horticulture, Bidhan Chandra

Krishi Viswavidyalaya,

Mohanpur, Nadia, West Bengal,

India

\section{Surajit Mitra}

Department of Post Harvest

Technology, Faculty of

Horticulture, Bidhan Chandra

Krishi Viswavidyalaya,

Mohanpur, Nadia, West Bengal,

India
Corresponding Author:

Rahul Sur

Department of Post Harvest

Technology, Faculty of

Horticulture, Bidhan Chandra

Krishi Viswavidyalaya,

Mohanpur, Nadia, West Bengal,

India

\section{Studies on nutritional and morphological quality of different cultivars of sweet potato}

\author{
Rahul Sur, Achintya Mahato, Arghya Mani and Surajit Mitra
}

DOI: https://doi.org/10.22271/chemi.2020.v8.i1aq.8697

\begin{abstract}
Fifteen cultivars of sweet potato (Ipomoea batatas L.) were harvested from the field of (All India Coordinated Research Project on Tuber Crops) AICRP, Horticulture Research Station, Mandouri and the analysis of biochemical composition was carried out to determine the best nutritive cultivars. It was carried out in the Post graduate lab, Department of Post Harvest Technology, Faculty of Horticulture, Bidhan Chandra Krishi Viswavidyalaya, Mohanpur, Nadia West Bengal, during the period from 20172019.

It was found that the tuber weight was varied significantly from $48.11 \mathrm{gm}$ to $540.45 \mathrm{gm}$ among the different cultivars. The tuber length was recorded high in TSP-16-2 $(12.22 \mathrm{~cm})$ and short in cultivar BCSP-10 $(6.75 \mathrm{~cm})$.Maximum TSS value recorded in KISHAN $\left(10.2^{\circ}\right.$ Brix) and the lowest value was recorded cultivar TSP-12-10 ( $8^{\circ}$ Brix). Dry matter content was found higher in the cultivars TSP-12-6 $(30.54 \%)$. Minimum content of dry matter was found in TSP-12-9 (23.55\%). The highest total sugar value was found in the cultivars TSP-16-5 (2.55\%). The cultivar with lowest total sugar content was found in TSP-16-8 (1.94\%). The result indicated that the cultivars differed considerably in reducing sugars content. In the experiment highest content was found to be in the cultivar BCSP-10(1.21\%). Lowest was found in the cultivars TSP-12-10 $(0.83 \%)$. The highest Titratable acidity value was found in the cultivars KISHAN $(0.416 \%)$ and Lowest was found in the cultivars TSP-12-10 (0.128\%).
\end{abstract}

Keywords: Nutritional, morphological quality, cultivars, sweet potato

\section{Introduction}

Sweet potato (Ipomoea batatas) is non dicotyledonous plant which belongs to the family of Convolvulaceae (Tortoe, 2010) ${ }^{[20]}$ grown as a starchy food crop throughout the tropical, subtropical and frost-free temperate climate zones in the world (ICAR, 2007) ${ }^{[11]}$. It is among the world's most important versatile and underutilized food crop grown generally for its storage roots (Tortoe, 2010) ${ }^{[20]}$. It is a minor root crop in tropical Africa and despite its industrial potentials as indicated by its growth in terms of production. Among the root and tuber crops, it is the only one that had a positive per capita annual rate of increase in production in SubSaharan Africa. It has been a life saver for centuries in many tropical, sub-tropical and warmer temperate areas of the world, warding off famine in times of both climatic disaster and war produces storage roots rich in carbohydrates and $\beta$-carotene, a precursor of vitamin $\mathrm{A}$, and its leaves are rich in proteins. The roots also contain vitamins $\mathrm{C}, \mathrm{B}$ complex, and $\mathrm{E}$ as well as potassium, calcium, and iron. Purple-fleshed ones contain antioxidants such as anthocyanins. In world crop statistics, the sweet potato is ranked seventh, just after cassava, with an annual production around $9 \mathrm{Mt}$ and a cultivated area of 110 Mha (FAO, 2009) ${ }^{[6]}$

Sweet potato originated in the Central or South American low lands. Some remains were also found in the Casma valley of Peru as far back as 2000 B.C. Today, it is cultivated in more than a 100 countries in the world. Sweet potato is cultivated extensively for its nutritious and

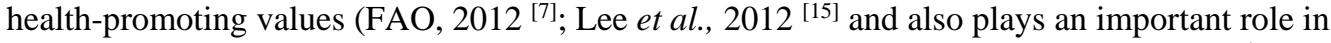
food security. The production reached over 100 million tons in 2014 (FAOSTAT, 2016) ${ }^{[8]}$

Sweet potato is ranked one of the most important food crop after rice, wheat, potato, maize, and cassava (Shekhar et al., 2015) ${ }^{[19]}$. The total production in India is about 1338 thousand tons and area is 110.63 thousands hectare. In West Bengal the area under sweet potato cultivation is 22.85 thousands hectare and production of sweet potato is about 442.28 thousand tons. It grows under many ecological conditions, has a shorter growth period than most crops and shows no marked seasonality. 
In most developing countries, it is a smallholder crop tolerant of a wide range of edaphic and climatic conditions and grown with limited inputs. It is also quite tolerant of cold and being cultivated at altitudes as high as $2,500 \mathrm{~m}$, it has become the staple of communities living in the highlands of Uganda, Rwanda, and Burundi in Eastern Africa and in Papua New Guinea where annual per capita fresh roots consumption is over $150 \mathrm{~kg}$. Asia is the largest producing region and China alone accounts for almost $60 \%$ of world production. In the southern provinces of Sichuan and Shandong, sweet potato is a major source of raw material for food processing industries (Fuglie and Hermann, 2004) ${ }^{[9]}$. Nearly half of the Chinese production is for animal feed (roots and leaves), with the remainder primarily used for human consumption, either as fresh (boiled roots) or processed products (noodles and alcohol). In some temperate countries such as the United States, Japan, and New Zealand, the sweet potato is a highquality luxury vegetable.

Sweet potato plays a major role as a famine reserve for many rural and urban households because of its tolerance to drought, short growth and high yield with limited inputs on relatively marginal soils. Sweet potato cultivars are rich in dietary fiber, minerals, vitamins and antioxidants, including anthocyanins, phenolic acids, beta-carotene and tocopherol

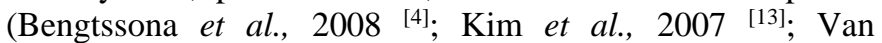

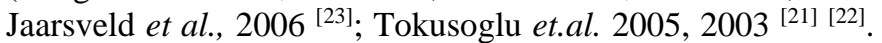
Roots, stems and leaves of sweet potatoes are edible parts with varying composition of nutrients, bioactive, nonnutrients and anti nutrients.It is a low input crop and it is used as a vegetable, dessert, source of starch and it is eaten as a substitute for yam due to its lower cost of production. Sweet potato is comparatively a nutritional heavy weight; rich in complex carbohydrates, vitamins $\mathrm{C}$ and $\mathrm{E}$, and also contains good quantities of vitamins $\mathrm{A}$ and $\mathrm{B}$, calcium and iron. India has a long history of cultivation of sweet potato (Ipomoea batatas) which is one such crop rich in $\beta$-carotene, a precursor of vitamin A. Sweet potato has been reported to contain both organic and mineral nutrients including vitamins $\mathrm{A}$ and $\mathrm{C}$, zinc, potassium, sodium, manganese, calcium and magnesium.

\section{Materials and Methods}

Fifteen cultivars of sweet potato (Ipomoea batatas L.) were harvested from the field of (All India Coordinated Research Project on Tuber Crops) AICRP, Horticulture Research Station, Mandouri after 120 days and brought in the lab for analysis of biochemical composition in order to determine the best nutritive cultivars.

Treatment details: The varieties of sweet potato which were evaluated for nutritional aspect assessment are actually the individual treatments.

$\mathrm{T}_{1}=$ KISHAN, $\mathrm{T}_{2}=$ SRIBHADRA, $\mathrm{T}_{3}=\mathrm{ST}-14, \mathrm{~T}_{4}=\mathrm{BCSP}-10$, $\mathrm{T}_{5}=\mathrm{TSP}-12-4, \mathrm{~T}_{6}=\mathrm{TSP}-12-6, \mathrm{~T}_{7}=\mathrm{TSP}-12-7, \mathrm{~T}_{8}=\mathrm{TSP}-12-9$, $\mathrm{T}_{9}=\mathrm{TSP}-12-10, \mathrm{~T}_{10}=\mathrm{TSP}-12-12, \mathrm{~T}_{11}=\mathrm{TSP}-12-14, \quad \mathrm{~T}_{12}=\mathrm{TSP}-$ 16-2, $\mathrm{T}_{13}=\mathrm{TSP}-16-3, \mathrm{~T}_{14}=\mathrm{TSP}-16-5, \mathrm{~T}_{15}=\mathrm{TSP}-16-8$.

\section{Observations recorded}

A. Physical parameters evaluated

1. Tuber weight (gm)

2. Tuber length $(\mathrm{cm})$

3. Tuber diameter $(\mathrm{cm})$

4. Tuber shape.

5. Flesh colour.

6. Skin colour.

\section{Bio-chemical and other quality parameters}

1. Moisture content $(\%)$

2. Dry matter content $(\%)$

3. $\operatorname{TSS}\left({ }^{\circ} \mathrm{B}\right)$

4. Total sugar content (\%)

5. Reducing sugar content (\%)

6. Non reducing sugar content $(\%)$

7. Titratable acidity $(\%)$

\section{Preliminary preparation for experiment}

Washing: Sweet potato tubers were washed in tap water after that in distilled water containing $50 \mathrm{ppm}$ of chlorine to get rid of any foreign material that may be adhering to the tuber surface and also to reduce the microbial count.

Drying: There after the sweet potato tubers were dried under electric fan.

Moisture content (\%): The sample was dried in drier at 66 ${ }^{\circ} \mathrm{C}$ and initial and final weight was recorded by weighing balance.

$(\%)$ moisture $=\frac{\text { Final value }- \text { initial value } \times 100}{\text { Initial value }}$

Dry matter content $(\%)$ : Dry matter of harvested tubers of different cultivars was recorded in gram after drying the samples in drier at $66^{\circ} \mathrm{C}$ for few hours.

Total soluble solid $\left({ }^{\circ} \mathbf{B}\right)$ : A total soluble solid was determined by using a Hand Refractrometer.

Total sugar (\%): Sugar level was determined by copper reduction Lane and eynon method (Ranganna, 2000) ${ }^{[17]}$.

Reducing sugar (\%): Sugar level was determined by copper reduction Lane and eynon method (Ranganna, 2000) ${ }^{[17]}$.

Non reducing sugar (\%): Non reducing sugar content was determined by deducting the reducing sugar from the total sugar content.

Titratable acidity $(\%)$

It was estimated as per Sadasivam and Manickam (1996) ${ }^{[18]}$ which provide a measure of organic acids in the fruits (expressed as \% anhydrous citric acid).

\section{Statistical Analysis}

The analysis of data obtained in experiment was analyzed by Completely Randomized Design method by adopting the statistical procedures of Gomez and Gomez, (1984) ${ }^{[10]}$. 


\section{Result and Discussion}

Table 1: Sweet potato characters (root skin and flesh colour, weight, length and girth) of Sweet potato cultivars

\begin{tabular}{|c|c|c|}
\hline Sl. no. & Cultivars & Morphological characteristics of sweet potato \\
\hline 1. & KISHAN & $\begin{array}{l}\text { Sweet potato tuber shape is long elliptical. Predominant skin colour is purple. Predominant flesh colour is white. } \\
\text { Average weight of tuber is } 133.33 \mathrm{gm} \text {. Average length is } 13.73 \mathrm{~cm} \text { Average diameter of tuber is } 6.49 \mathrm{~cm} \text {. }\end{array}$ \\
\hline 2. & SRIBHADRA & $\begin{array}{l}\text { Tuber shape is long elliptical. Predominant skin colour is white pinkish. Predominant flesh colour is off yellowish. } \\
\text { Average weight of tuber is } 540.45 \mathrm{gm} \text {. Average length is } 10.45 \mathrm{~cm} \text { Average diameter of tuber is } 9.15 \mathrm{~cm} \text {. }\end{array}$ \\
\hline 3. & ST 14 & $\begin{array}{c}\text { Tubers are curved. Predominant skin colour is orange. Predominant flesh colour is deep orange. Average weight of } \\
\text { tuber is } 120.74 \mathrm{gm} \text {. Average length is } 9.92 \mathrm{~cm} \text {. Average diameter of tuber is } 10.24 \mathrm{~cm} \text {. }\end{array}$ \\
\hline 4. & BCSP 10 & $\begin{array}{l}\text { Sweet potato tuber shape is long elliptical. Predominant skin colour is purple. Predominant flesh colour is white. } \\
\text { Average weight of tuber is } 70.16 \mathrm{gm} \text {. Average length is } 6.75 \mathrm{~cm} \text { Average diameter of tuber is } 3.46 \mathrm{~cm} \text {. }\end{array}$ \\
\hline 5. & TSP-12-4 & $\begin{array}{l}\text { Sweet potato tuber shape is long elliptical. Predominant skin colour is purple. Predominant flesh colour is white. } \\
\text { Average weight of tuber is } 198.22 \mathrm{gm} \text {. Average length is } 10.63 \mathrm{~cm} \text { Average diameter of tuber is } 5.35 \mathrm{~cm} \text {. }\end{array}$ \\
\hline 6. & TSP-12-6 & $\begin{array}{l}\text { Sweet potato tuber shape is long elliptical. Predominant skin colour is purple. Predominant flesh colour is white. } \\
\text { Average weight of tuber is } 71.45 \text {. Average length is } \mathrm{cm} 7.36 \text { Average diameter of tuber is } 4.62 \mathrm{~cm} \text {. }\end{array}$ \\
\hline 7. & TSP-12-7 & $\begin{array}{l}\text { Sweet potato tuber shape is long elliptical. Predominant skin colour is purple. Predominant flesh colour is white. } \\
\text { Average weight of tuber is } 48.11 \mathrm{gm} \text {. Average length is } 8.27 \mathrm{~cm} \text { Average diameter of tuber is } 4.2 \mathrm{~cm} \text {. }\end{array}$ \\
\hline 8. & TSP-12-9 & $\begin{array}{l}\text { Sweet potato tuber shape is long elliptical. Predominant skin colour is light pinkish. Predominant flesh colour is off } \\
\text { white. Average weight of tuber is } 170.66 \mathrm{gm} \text {. Average length is } 10.29 \mathrm{~cm} \text { Average diameter of tuber is } 6.79 \mathrm{~cm} \text {. }\end{array}$ \\
\hline 9. & TSP-12-10 & $\begin{array}{l}\text { Sweet potato tuber shape is long elliptical. Predominant skin colour is purple. Predominant flesh colour is white. } \\
\text { Average weight of tuber is } 145.5 \mathrm{gm} \text {. Average length is } 7.49 \mathrm{~cm} \text { Average diameter of tuber is } 4.21 \mathrm{~cm} \text {. }\end{array}$ \\
\hline 10. & TSP-12-12 & $\begin{array}{l}\text { Sweet potato tuber shape is round elliptical. Predominant skin colour is purple. Predominant flesh colour is white. } \\
\text { Average weight of tuber is } 185.75 \mathrm{gm} \text {. Average length is } 8.52 \mathrm{~cm} \text { Average diameter of tuber is } 5.46 \mathrm{~cm} \text {. }\end{array}$ \\
\hline 11. & TSP-12-14 & $\begin{array}{l}\text { Sweet potato tuber shape is roundish. Predominant skin colour is light purple. Predominant flesh colour is white. } \\
\text { Average weight of tuber is } 162.42 \mathrm{gm} \text {. Average length is } 7.16 \mathrm{~cm} \text { Average diameter of tuber is } 5.47 \mathrm{~cm} \text {. }\end{array}$ \\
\hline $12 .$. & TSP-16-2 & $\begin{array}{l}\text { Sweet potato tuber shape is long elliptical. Predominant skin colour is white pinkish. Predominant flesh colour little } \\
\text { yellowish. Average weight of tuber is } 470.45 \mathrm{gm} \text {. Average length is } 12.22 \mathrm{~cm} \text { Average diameter of tuber is } 7.76 \mathrm{~cm} \text {. }\end{array}$ \\
\hline 13. & TSP-16-3 & $\begin{array}{l}\text { Sweet potato tuber shape is long elliptical. Predominant skin colour is white pinkish. Predominant flesh colour is } \\
\text { deep orange Average weight of tuber is } 220.59 \mathrm{gm} \text {. Average length is } 9.56 \mathrm{~cm} \text { Average diameter of tuber is } 5.95 \mathrm{~cm} \text {. }\end{array}$ \\
\hline 14. & TSP-16-5 & $\begin{array}{l}\text { Sweet potato tuber shape is round elliptical. Predominant skin colour is purple. Predominant flesh colour is deep } \\
\text { orange. Average weight of tuber is } 425.73 \mathrm{gm} \text {. Average length is } 8.16 \mathrm{~cm} \text { Average diameter of tuber is } 6.4 \mathrm{~cm} \text {. }\end{array}$ \\
\hline 15. & TSP-16-8 & $\begin{array}{l}\text { Sweet potato tuber shape is curved. Predominant skin colour is white pinkish. Predominant flesh colour is white. } \\
\text { Average weight of tuber is } 337.43 \mathrm{gm} \text {. Average Tuber length is } 7.66 \mathrm{~cm} \text { Average diameter of tuber is } 5.12 \mathrm{~cm} \text {. }\end{array}$ \\
\hline
\end{tabular}

Table 2: Physical parameters (weight, length and Tuber diameter) of sweet potato Cultivar

\begin{tabular}{|c|c|c|c|}
\hline Cultivars & Tuber weigh & Tuber length & Tuber diameter \\
\hline KISHAN & 133.33 & 9.73 & 6.49 \\
\hline SRIBHADRA & 540.45 & 10.45 & 9.15 \\
\hline ST 14 & 220.74 & 9.92 & 10.24 \\
\hline BCSP 10 & 70.16 & 6.75 & 3.46 \\
\hline TSP-12-4 & 198.22 & 10.63 & 5.35 \\
\hline TSP-12-6 & 71.45 & 7.36 & 4.62 \\
\hline TSP-12-7 & 48.11 & 8.27 & 4.2 \\
\hline TSP-12-9 & 170.66 & 10.29 & 6.79 \\
\hline TSP-12-10 & 145.5 & 7.49 & 4.21 \\
\hline TSP-12-12 & 185.75 & 8.52 & 5.46 \\
\hline TSP-12-14 & 162.42 & 7.16 & 5.47 \\
\hline TSP-16-2 & 470.45 & 12.22 & 7.76 \\
\hline TSP-16-3 & 220.59 & 9.56 & 5.95 \\
\hline TSP-16-5 & 425.73 & 8.16 & 6.4 \\
\hline TSP-16-8 & 337.43 & 7.66 & 5.12 \\
\hline
\end{tabular}

\section{Tuber weight (gm)}

Tuber weight was varied significantly from $48.11 \mathrm{gm}$ to $540.45 \mathrm{gm}$ among the different cultivars. The tuber weight was recorded very high in SRIBHADRA (540.45gm), followed by TSP-16-2 (470.45gm) and the lowest tuber weight was recorded in TSP-12-7 (48.11g), BCSP10(70.16gm), TSP-12-6(71.45gm). Bhattacharya, N. (2001) [2].

\section{Tuber length $(\mathbf{c m})$}

Tuber length varied significantly from $6.75 \mathrm{~cm}$ to $12.22 \mathrm{~cm}$ among the different sweet potato cultivars. The tuber length was recorded high in TSP-16-2 $(12.22 \mathrm{~cm})$ followed by TSP-
$12-4(10.63 \mathrm{~cm})$ and short in cultivar BCSP-10 $(6.75 \mathrm{~cm})$. Bhattacharya, N. (2001) ${ }^{[2]}$.

\section{Tuber diameter $(\mathrm{cm})$}

Tuber diameter was varied from $3.46 \mathrm{~cm}$ to $10.24 \mathrm{~cm}$ among the different sweet potato cultivars. The tuber diameter was recorded maximum in $\mathrm{ST}-14(10.24 \mathrm{~cm})$ followed by SRIBHADRA $(9.15 \mathrm{~cm}), \quad$ TSP-16-2 $(7.76 \mathrm{~cm})$ and the minimum tuber girth were recorded in cultivar BCSP-10 $(3.46 \mathrm{~cm})$. Bhattacharya, N. $(2001)^{[2]}$.

Table 3: Biochemical attributes of different sweet potato cultivars.

\begin{tabular}{|c|c|c|c|}
\hline Cultivars & TSS ( $\left.{ }^{\mathbf{} B r i x}\right)$ & Dry Matter (\%) & Moisture (\%) \\
\hline KISHAN & 10.2 & 29.55 & 70.45 \\
\hline SRIBHADRA & 8.4 & 24.51 & 75.49 \\
\hline ST 14 & 9.6 & 26.52 & 73.48 \\
\hline BCSP 10 & 9.8 & 29.93 & 70.07 \\
\hline TSP-12-4 & 9.2 & 28.75 & 71.25 \\
\hline TSP-12-6 & 8.6 & 30.54 & 69.46 \\
\hline TSP-12-7 & 8.8 & 27.50 & 72.50 \\
\hline TSP-12-9 & 8.2 & 23.55 & 76.45 \\
\hline TSP-12-10 & 8 & 25.39 & 74.61 \\
\hline TSP-12-12 & 9.2 & 29.86 & 70.14 \\
\hline TSP-12-14 & 9.8 & 29.47 & 70.53 \\
\hline TSP-16-2 & 9 & 26.40 & 73.60 \\
\hline TSP-16-3 & 9.2 & 27.46 & 72.54 \\
\hline TSP-16-5 & 9.4 & 25.56 & 74.44 \\
\hline TSP-16-8 & 9.2 & 25.59 & 74.41 \\
\hline MEAN & 9.10 & 27.37 & 72.63 \\
\hline S.Em $( \pm)$ & 0.058 & 0.175 & 0.175 \\
\hline CD 5\% & 0.168 & 0.508 & 0.508 \\
\hline \multicolumn{4}{|c}{}
\end{tabular}


Studies on bio-chemical properties of sweet potato tubers

During observation of sweet potato cultivars TSS, dry matter content, moisture percentage varies from cultivars to cultivars.

\section{Total Soluble Solids (TSS) Content}

The data presented in table indicated that TSS varies cultivars to cultivars, its varies from 8.0 to $10.2^{\circ}$ Brix. Maximum TSS value recorded in KISHAN $\left(10.2^{\circ}\right.$ Brix) followed by cultivars BCSP 10 (9.8 ${ }^{\circ}$ Brix), TSP-12-14 (9.8 ${ }^{\circ}$ Brix), ST-14 $\left(9.7^{\circ}\right.$ Brix $)$. The lowest value was recorded cultivar TSP-12-10 ( $\left.8^{\circ} \mathrm{Brix}\right)$.

\section{Dry Matter (\%)}

Dry matter content was found higher in the cultivars TSP-12$6(30.54 \%)$ followed by BCSP -10 (29.93\%) TSP-1212(29.86\%), KISHAN (29.55\%). Minimum content of dry matter was found in TSP-12-9(23.55\%).

These results correlate with the findings of Vasudevan et al.

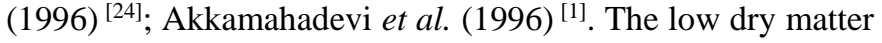
content may be due to presence of high moisture in the tuber. The average dry matter content is $26.27 \%$, but varies according to cultivar, climate, soil conditions and agronomic practices (Ingabire and Vasanthakaalam, 2011) ${ }^{[12]}$.

\section{Moisture (\%)}

Moisture percentage of sweet potato tubers was also varied significantly among the different culltivars. The maximum value was recorded in TSP-12-9 (76.45\%) followed by SRIBHADRA (75.49\%), TSP-12-1 (74.61\%). Minimum moisture content was found in TSP-12-6 (69.46\%).

Table 4: Bio chemicals attributes of different sweet potato cultivars

\begin{tabular}{|c|c|c|c|c|}
\hline Cultivars & $\begin{array}{c}\text { Total } \\
\text { Sugar } \\
(\boldsymbol{\%})\end{array}$ & $\begin{array}{c}\text { Reducing } \\
\text { Sugar } \\
(\boldsymbol{\%})\end{array}$ & $\begin{array}{c}\text { Non- } \\
\text { Reducing } \\
\text { Sugar }(\boldsymbol{\%})\end{array}$ & $\begin{array}{c}\text { Acidity } \\
(\boldsymbol{\%})\end{array}$ \\
\hline KISHAN & 2.20 & 1.14 & 1.06 & 0.416 \\
\hline SRIBHADRA & 2.02 & 1.12 & 0.90 & 0.256 \\
\hline ST 14 & 2.45 & 1.17 & 1.28 & 0.224 \\
\hline BCSP 10 & 2.06 & 1.21 & 0.85 & 0.32 \\
\hline TSP-12-4 & 1.95 & 1.05 & 0.90 & 0.352 \\
\hline TSP-12-6 & 2.15 & 1.15 & 1.0 & 0.224 \\
\hline TSP-12-7 & 2.35 & 1.19 & 1.16 & 0.16 \\
\hline TSP-12-9 & 2.10 & 1.13 & 0.97 & 0.256 \\
\hline TSP-12-10 & 2.00 & 1.17 & 0.83 & 0.128 \\
\hline TSP-12-12 & 2.40 & 1.14 & 1.26 & 0.224 \\
\hline TSP-12-14 & 2.15 & 1.16 & 0.99 & 0.352 \\
\hline TSP-16-2 & 2.05 & 1.13 & 0.92 & 0.32 \\
\hline TSP-16-3 & 1.98 & 1.07 & 0.91 & 0.352 \\
\hline TSP-16-5 & 2.55 & 1.19 & 1.36 & 0.288 \\
\hline TSP-16-8 & 1.94 & 1.06 & 0.88 & 0.288 \\
\hline MEAN & 2.16 & 1.14 & 1.01 & 0.277 \\
\hline S.Em $( \pm)$ & 0.036 & 0.020 & 0.017 & 0.018 \\
\hline CD 5\% & 0.106 & 0.058 & 0.050 & 0.054 \\
\hline
\end{tabular}

\section{Total Sugar}

Considerable cultivar specific differences in total sugar content of tubers were also recorded. Total sugar content varies from $2.55 \%$ to 1.94 the highest value was found in the cultivars TSP-16-5 (2.55\%), followed by ST-14(2.45\%). Lowest total sugar content was found in TSP-16-8 (1.94\%), followed by TSP-12-4(1.95\%).

Total sugars in stored, raw staple sweet potato types range from $1.9 \%$ to $3.2 \%$ on a fresh weight (FW) basis (Picha, 1986) ${ }^{[16]}$.These results correlate with the findings of (Chattopadhyay et al., 2002) ${ }^{[5]}$. Akkamaha devi et al. (1996) [1]

\section{Reducing Sugar}

The result indicated that the cultivars differed considerably in reducing sugars content. In the experiment highest content was found to be in the cultivar BCSP-10(1.21\%) followed by TSP-16-5 (1.19\%), TSP-12-7 (1.19\%). Lowest was found in the cultivars TSP-12-4 (1.05\%).

These results correlate with the findings of (Chattopadhyay et al., 2002) ${ }^{[5]}$. Akkamaha devi et al. (1996) ${ }^{[1] .}$

\section{Non-Reducing Sugar}

Non reducing sugar content of tubers was varies considerable among the cultivars. In the experiment highest content was found to be in the cultivar TSP-16-5 (1.36\%), followed by ST-14 (1.28\%), TSP-12-12 (1.26\%). Lowest was found in the cultivars TSP-12-10 (0.83\%).

These results correlate with the findings of (Chattopadhyay et al., 2002) ${ }^{[5]}$.

Titratable Acidity: The result indicated that in sweet potato cultivars acidity present in very low scale. The highest value was found in the cultivars KISHAN $(0.416 \%)$ followed by TSP-12-4, (0.352\%), TSP-12-14 (0.352\%) TSP-16-3 $(0.352 \%)$. Lowest was found in the cultivars TSP-12-10 $(0.128 \%)$.

\section{Summary and Conclusion}

15 varieties of sweet potato were evaluated for its physicochemical and other important traits. Based on the assessment, it was found that the tuber weight was varied significantly from $48.11 \mathrm{gm}$ to $540.45 \mathrm{gm}$ among the different cultivars. This study help in selecting the best nutritive cultivars suitable for making various processed products such as chips and crisps, production of alcohol, flour, snacks, noodles, jam, candies, snacks or biscuits and maltose as a sweetener. Best variety among this cultivars found in KISHAN,ST-14,TSP12-14.

\section{Reference}

1. Akkamahadevi-Pasare B, Neera R, Srinivasan CN, Pushapa B, Rao N, Bharati P. Composition and cooking quality of five sweet potato varieties. Journal of Root Crops. 1996; 22(2):101-104.

2. Bhattacharya N. Growth development and tuber quality of sweet potato cultivars grown as rainfed under upland and low land situation. Ph. D. thesis submitted to B.C.K.V. Mohanpur, Nadia West Bengal. India, 2001.

3. Bengtsson A, Larsson Alminger M, Svanberg U. In vitro bioaccessibility of $\beta$-carotene from heat-processed orange-fleshed sweet potato. Journal of agricultural and food chemistry. 2009; 57(20):9693-9698.

4. Bengtsson A, Namutebi A, Alminger ML, Svanberg U. Effects of various traditional processing methods on the all-trans- $\beta$-carotene content of orange-fleshed sweet potato. Journal of food composition and analysis. 2008; 21(2):134-143.

5. Chattopadhyay A, Chakraborty I, Sen H. PhysicoChemical characteristics of sweetpotato as a function of cultivars. The Horticulture Journal. 2002; 15:45-50.

6. FAO (Food and Agriculture Organization of the United Nations), 2009.

7. FAO (Food and Agriculture Organization of the United Nations), 2012.

8. FAOSTAT (Statistics division of Food and Agriculture Organization of the United Nations), 2016. 
9. Fuglie KO. and Hermann, M. Introduction to Volume', in K. O. Fuglie and M. Hermann (edition), Sweet potato Post-Harvest Research and Development in China, Proceedings of an International Workshop held in Chengdu, Sichuan, PR China,7-8 November 2001(Bogor, Indonesia: International Potato Center (CIP), 2004.

10. Gomez KA, Gomez AA. Statistical procedures for Agricultural Research (2nd edition). Wiley- inter Science Publication (John Wiley and Sons) New York, USA, 1984.

11. ICAR (Indian Council of Agricultural Research). Handbook of Agriculture Directorate of Information and Publication, India Council Agriculture Research, New Delhi, 2007, 512-516.

12. Ingabire $\mathbf{M}$, Vasanthakaalam $\mathrm{H}$. Comparison of the nutrient composition of four sweet potato varieties cultivated in Rwanda. American journal of food and nutrition. 2011; 1(1):34-38.

13. Kim YN, Giraud DW, Driskell JA. Tocopherol and carotenoid contents of selected Korean fruits and vegetables. Journal of Food Composition and Analysis. 2007; 20(6):458-465.

14. Koehler PE, Kays SJ. Sweet potato flavor: quantitative and qualitative assessment of optimum sweetness. Journal of food quality. 1991; 14(3):241-249.

15. Lee MJ, Park JS, Choi DS, Jung MY. Characterization and quantitation of anthocyanins in purple-fleshed sweet potatoes cultivated in Korea by HPLC-DAD and HPLCESI-QTOF-MS/MS. Journal of agricultural and food chemistry. 2013; 61(12):3148-3158.

16. Picha DH. Sugar content of baked sweet potatoes from different cultivars and lengths of storage. Journal of food science. 1986; 51(3):845-848.

17. Ranganna S. In: Handbook of Analysis and Quality Control for fruits and vegetable Products. 2nd Edition, Tata McGraw Hill Publication Company Ltd. New Delhi, 2000.

18. Sadasivum S, Manickam A. Biochemical Methods. New age International publishers. 3rd edition, 2011.

19. Shekhar S, Mishra D, Buragohain AK, Chakraborty S, Chakraborty N. Comparative analysis of phytochemicals and nutrient availability in two contrasting cultivars of sweet potato (Ipomoea batatas L.). Food chemistry. 2015; 173:957-965.

20. Tortoe C, Obodai M, Amoa-Awua W. Microbial deterioration of white variety sweet potato (Ipomoea batatas) under different storage structures. International Journal of Plant Biology. 2010; 1(1):e10-e10.

21. Tokusoglu O, Kocak S, Aycan S, Yildirim Z. Comparative study for detection of B-group vitamins and folic acid by gas chromatograpy-mass spectrometry (GCMS) and differential pulse polarography (DPP) in sweet potato (Ipomea batatas L.). In 2003 IFT Annual Meeting Book of Abstracts, 2003, p. 239.

22. Tokusoglu O, Yildirim Z, Durucasu I. Nutraceutical phenolics (total polyphenols, chlorogenic [5-OCaffeoylquinic] acid) in tubers, leaves, stalks and stems of new developed sweet potato (Ipomea batatas L.): Alterations in tubers during short-term storage. Journal of Food Technology. 2005; 3(3):444-448.

23. Van Jaarsveld PJ, Marais DW, Harmse E, Nestel P, Rodriguez-Amaya DB. Retention of $\beta$-carotene in boiled, mashed orange-fleshed sweet potato. Journal of Food Composition and Analysis. 2006; 19(4):321-329.
24. Vasudevan K, Padmaja G, Jayakumar S. Induced tuber colour mutants and their biochemical characteristics in Sweet potato. Journal of Root Crops. 1996; 22:137-138. 